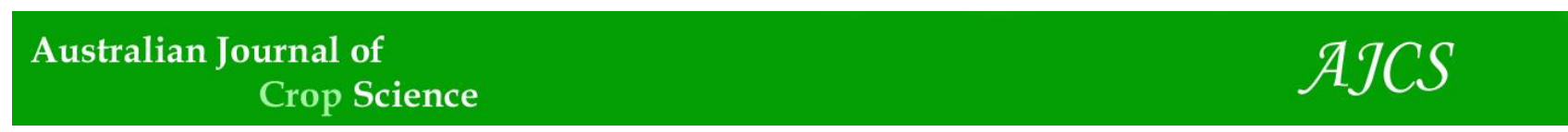

AJCS 11(09):1130-1136 (2017)

ISSN:1835-2707

doi: 10.21475/ajcs.17.11.09.pne598

\title{
Biochemical composition of oil palm fruits (Elaeis guineensis var. BRS Manicoré hybrid) in 11 years of growth and development
}

\section{Sabrina Santos de Lima, Ismael de Jesus Matos Viégas*, Heráclito Eugênio Oliveira da Conceição, Cândido Ferreira de Oliveira Neto, Ricardo Shigueru Okumura}

\section{Capanema Campus of the Universidade Federal Rural da Amazônia, Capanema city, State of Pará, Brazil}

\author{
*Corresponding author: ismael.viegas@ufra.edu.br
}

\begin{abstract}
The determination of biochemical composition during fruit development is important for understanding the metabolic and nutritional processes in oil palm. The main aim of this study was to determine the biochemical composition in oil palm fruits (BRS Manicoré hybrid) during the development. The experimental design was completely randomized with six evaluation periods $(4,5,6,7,9$ and 11 years of planting) in four replications. In oil palm fruits, concentration of total soluble carbohydrates was higher in $7^{\text {th }}$ year $(2.14$ mmol of glutamate $\left.\mathrm{g} \mathrm{DM}^{-1}\right)$; 9 (2.41 mmol of glutamate $\left.\mathrm{g} \mathrm{DM}^{-1}\right)$; and 11 years $\left(2.66\right.$ mmol of glutamate $\left.\mathrm{g} \mathrm{DM}^{-1}\right)$ of development. The total soluble amino acid had higher concentrations at $4^{\text {th }}$ and $5^{\text {th }}$ years with values of 112.11 and $105.97 \mu$ mol of amino acids $g$ $\mathrm{DM}^{-1}$, respectively. The total soluble protein was increased from $5\left(2.00 \mathrm{mg}\right.$ of protein $\left.\mathrm{g} \mathrm{DM}^{-1}\right)$ to 11 years $(2.19 \mathrm{mg}$ of protein $\mathrm{g}$ $\left.\mathrm{DM}^{-1}\right)$ during development of BRS Manicore. Regarding the sucrose concentration, the highest values were observed at $9(16.19 \mathrm{mg}$ of sucrose $\mathrm{g} \mathrm{DM}^{-1}$ ) and 11 years $\left(18.69 \mathrm{mg}\right.$ of sucrose $\left.\mathrm{g} \mathrm{DM}^{-1}\right)$, while for the starch concentration the best values were observed at 4 $\left(0.81 \mathrm{mmol}\right.$ of glutamate $\left.\mathrm{g} \mathrm{DM}^{-1}\right)$ and 5 years $\left(0.70 \mathrm{mmol}\right.$ of glutamate $\left.\mathrm{g} \mathrm{DM}^{-1}\right)$ of oil palm development. At the initial development stage of oil palm (4 to 5 years of planting) the total soluble amino acids $\left(112.11 \mu\right.$ mol of amino acids $\left.\mathrm{g} \mathrm{DM}^{-1}\right)$ and starch concentrations $\left(0.81 \mathrm{mmol}\right.$ of glutamate $\left.\mathrm{g} \mathrm{DM}^{-1}\right)$ showed higher values. The results showed that at 11 years of planting BRS Manicoré hybrid presented higher values of soluble carbohydrates $\left(2.66 \mathrm{mmol}\right.$ of glutamate $\left.\mathrm{g} \mathrm{DM}^{-1}\right)$, sucrose $(18.69 \mathrm{mg}$ of sucrose $\mathrm{g}$ $\mathrm{DM}^{-1}$ ) and protein concentration $\left(2.19 \mathrm{mg}\right.$ of protein $\left.\mathrm{g} \mathrm{DM}^{-1}\right)$. After 11 years of oil palm development, the products supposed to be the highest, the age at which greater accumulations of biochemical compounds may occur in fruits.
\end{abstract}

Keywords: carbohydrates, amino acids, starch, sucrose, total soluble proteins.

Abbreviations: DM_dry matter, GLU_glutamate, AA_amino acid, GS-GOGAT pathway_glutamine synthetase/glutamate synthase, $\mathrm{NH}_{4}^{+}$_ammonia.

\section{Introduction}

The oil palm tree has great importance in agro-ecology and industrial activity. Its commercial exploitation period is approximately 25 years and the plant's oil yield is 3 to 8 times higher than other oil seeds. This fact makes this tree so attractive to farmers, by which the planting has expanded rapidly in the Brazilian Amazon in the past decades (Rist et al., 2010; Villela et al., 2014).

There are two types of oil that can be obtained from the oil palm fruits: palm oil from the flesh of the fruit (mesocarp), and palm kernel oil from the seed or kernel (Tan et al., 2009; Borges et al., 2016). The main fatty acids in palm oil are palmitic acids, oleic acid and linoleic acid, while palm kernel oil is rich in lauric acid and is similar to coconut oil (Kok et al., 2011).

The oil palm fruits present approximately $50 \%$ saturated fatty acids (palmitic 44\%, and stearic 5\%) and $50 \%$ unsaturated fatty acids (40\% oleic, and $10 \%$ linoleic), showing a good variety of oil components. This specific characterization of oil obtained from palm oil promotes its application in several products, such as food industry, chemical, cosmetic and fuel (Sambanthamurthi et al., 2000).

The oil palm presents wide variability of products in the national and international markets, demonstrating the importance of investigation on plant metabolites that promote the crop yield. However, existence of metabolites is very susceptible in plant tissues, through modification or alteration in environmental conditions, such as air temperature, rainfall, luminosity, and mineral nutrition (Silva et al., 2016).

Chemical composition of fruits is essential to understand the nutritional requirements of plant. Subsequently, the information promotes subsidy to estimate the amount of nutrients to be supplied to plants through fertilization. In general, oil palm plants exhibit different behavior during development, presenting alterations in biochemical concentrations in leaf tissue, which consequently change the concentrations of oils in fruits in oil palm. In general, younger foliar tissues have a high biosynthetic activity, increasing the production of several biochemical compounds. This affects distribution and redistribution of the metabolites to the fruits, through biochemical (internal redistribution) and biogeochemical cycles.

According to Tranbarger et al. (2011) the fruit of oil palm completed their development, maturation and ripening in approximately 160 days, with five distinct phases of mesocarp development. The Phase I, between 30 and 60 days after pollination (DAP), is defined by anticlinal cell divisions and expansion along with the initial increase in fruit mass and size. The Phase II, between 60 and 100 DAP, is a transition 
period characterized by a lag in the accumulation of fresh mass and also by peak amounts of indole-3-acetic acid (IAA) and IAA conjugates; Phase III, between 100 and 120 DAP, is the end of the transition period, during which decreases in auxin, gibberellic acid (GA), and cytokinin metabolites are observed; Phase IV, between 120 and 140 DAP, is characterized by lipid (more than $2 \mathrm{~g}$ per fruit) and carotenoid accumulation. In addition, the low amounts of all hormone metabolites, including auxin, GA and cytokinin, ABA, and ethylene were observed in phase IV. Finally, during the ripening phase $\mathrm{V}$, there is a large increase in the hormones $\mathrm{ABA}$ and ethylene, and cell wall detachment related to ripening processes in the mesocarp, dry and fresh fruit mass increase massively, concurrently with lipid and carotenoid accumulation in the mesocarp. As observed at 160 DAP, lipids accumulate within subcellular spherical organelles (10$15 \mu \mathrm{m}$ in diameter, six to 12 per mesocarp cell) that occupy the volume of the cells.

Basic information about the concentrations of metabolites in oil palm fruit is scarce. There is no information for the BRS Manicoré hybrid (Elaeis oleífera $\times$ Elaeis guineensis), produced by Brazilian company Embrapa - Amazônia Ocidental. The main features of this hybrid inherited from $E$. oleifera are resistance to lethal yellowing (Collares, 2011), a disease associated with phytoplasmas (Beakbane et al., 1972), while high oil production was inherited from $E$. guineensis (Collares, 2011). Thus, this hybrid presents a great commercial interest for being the single genetics plant resistant to lethal yellowing of oil palm.

The limited information on total soluble carbohydrates, total soluble amino acids, total soluble proteins, sucrose, and starch concentrations. In addition to few studies on oil palm tree grown under greenhouse conditions and/or considering only one year of evaluation, the aims of study were to determine the biochemical composition of oil palm fruits (Elaeis guineensis var. BRS Manicoré hybrid) in 11 years of growth and development.

\section{Results and Discussion}

\section{Summary of variance analysis}

The factor characterized by years of growth and development of oil palm fruit showed significant for all evaluated variables in analysis of variance (Table 1). From the information in Table 1 , verified low values of coefficients of variation, with values lower than $17 \%$ for evaluated variables, proved good experimental accuracy.

\section{Total soluble carbohydrates}

The total soluble carbohydrates concentrations were increased with better adjustment of linear equation $(\mathrm{Y}=$ $\left.0.19 \mathrm{X}+0.59 \mathrm{R}^{2}=0.95\right)$, observing that most significant concentrations were at $7\left(2.14 \mathrm{mmol}\right.$ of glutamate $\left.\mathrm{g} \mathrm{DM}^{-1}\right), 9$ (2.41 mmol of glutamate $\left.\mathrm{g} \mathrm{DM}^{-1}\right)$, and 11 years of planting (2.66 mmol of glutamate $\mathrm{g} \mathrm{DM}^{-1}$ ) of BRS Manicoré development (Fig 1).

The increase in carbohydrate concentration from the 7 years of planting shows that plant assimilated the nutrients, especially nitrogen through the influence of nitrogen fertilization with urea, increasing the capacity of metabolic drains and formation of photosynthetic components. Sousa (2013), reported variations in total soluble carbohydrates concentration in açaí fruit, as function of years and the highest concentration was observed at 6 years of planting with $0.35 \mathrm{mmol}$ of glutamate $\mathrm{g} \mathrm{DM}^{-1}$.

\section{Total soluble amino acids}

The values of total soluble amino acids concentrations were decreased, adjusted to a linear equation $(\mathrm{Y}=-4.33 \mathrm{X}+127.08$ $\left.\mathrm{R}^{2}=0.97\right)$ with higher concentrations of 112.11 and 105.97 $\mu \mathrm{mol}$ of amino acids $\mathrm{g} \mathrm{DM}^{-1}$ in the plants evaluated at 4 and 5 years of planting, respectively. Subsequently, the values decreased at 9 and 11 years of oil palm (Fig 2).

The increase of the shade in oil palm associated with the adequate supply of $\mathrm{N}$ (Cruz et al., 2005) promoted a greater metabolism of glutamine synthetase/glutamate synthase (GSGOGAT pathway), consuming the $\mathrm{NH}_{4}{ }^{+}$for the production of amino acids, posteriorly formation of proteins in oil palm.

In the first years, oil palm showed a period of lower shading and higher availability of $\mathrm{N}$. This promoted high photosynthetic rates, justifying high concentrations of amino acids at the beginning of oil palm development. Subsequently total amino acid value was reduced possibly due to use of amino acids for the formation of protein in plant.

According to Camargos et al. (2004), upon $\mathrm{N}$ availability, the nitrate is uptake by roots and can be reduced or stored in vacuoles or translocated to aerial part, in which it will be reduced or stored in the leaf vacuoles. In cytosol, nitrate is transformed to nitrite, entering the plastids. This will be changed to form ammonia, synthesizing to amino acids, glutamine and glutamate (Taiz and Zeiger, 2013) and protein formation, resulting in adequate leaf development. Sousa (2013) evaluated the total soluble amino acids concentration in açaí fruits and observed an increase in amino acid concentration at the fourth year of planting, with a subsequent reduction in values, similar to results obtained in present study.

\section{Proteins}

The protein concentration showed the better adjustment of linear equation $\left(\mathrm{Y}=0.033 \mathrm{X}+1.85 \mathrm{R}^{2}=0.97\right)$, observing an increase in the protein concentration during the BRS Manicoré development, with the highest values obtained at 11 years of planting (2.19 $\mathrm{mg}$ of protein $\mathrm{g} \mathrm{DM}^{-1}$ ) (Fig 3).

The increase in protein concentration was promoted by carbon assimilation through photosynthetic reactions as well as degradation of amino acids for protein formation (Benicasa, 2004) (Fig 2), in which the decrease in amino acids concentration. Sousa (2013) evaluated the protein concentration in açaí fruit and observed a linear growth, between the 2 and the 7 years of planting, showing variations from 0.0 to $15.81 \mathrm{mg}$ of protein $\mathrm{g} \mathrm{DM}^{-1}$, during the plant development.

\section{Sucrose}

The highest sucrose concentration was observed at 11 years of planting (18.69 mg of sucrose $\mathrm{g} \mathrm{DM}^{-1}$ ) (Fig 4), compared to other periods of evaluation of oil palm development. The sucrose concentrations were increasing and adjusted to a linear model $\left(\mathrm{Y}=1.76 \mathrm{X}+0.087 \mathrm{R}^{2}=0.97\right)$. The highest sucrose concentration was obtained at phenological stage of maturation of oil palm. Sucrose is a constituent that promotes changes during fruit maturation. In general, the sucrose concentrations increased with the development of fruits, resulting from the hydrolysis of starch, accumulated in plant 
Table 1. Summary of variance analysis and the mean of total soluble carbohydrates (TSC), total soluble amino acids (AA), total soluble proteins (PROT), sucrose (SUCR), and starch (STH) concentrations in oil palm fruit as function of 11 years of growth and development.

\begin{tabular}{|c|c|c|c|c|c|c|}
\hline \multirow[t]{2}{*}{ Font of variations } & \multirow{2}{*}{$\begin{array}{c}\text { Degrees of } \\
\text { freedom }\end{array}$} & \multicolumn{5}{|c|}{ Mean square } \\
\hline & & TSC & AA & PROT & SUCR & STH \\
\hline Years & 5 & $1.26^{*}$ & $538.02^{*}$ & $0.11^{*}$ & $100.34^{*}$ & $0.194^{*}$ \\
\hline Block & 3 & $0.02^{\mathrm{ns}}$ & $27.67^{\mathrm{ns}}$ & $0.05^{\mathrm{ns}}$ & $0.54^{\mathrm{ns}}$ & $0.004^{\mathrm{ns}}$ \\
\hline Residue & 15 & 0.10 & 23.10 & 0.03 & 1.95 & 0.005 \\
\hline General average & & 1.98 & 96.77 & 2.08 & 12.45 & 0.528 \\
\hline $\mathrm{CV}(\%)$ & & 16.34 & 4.97 & 10.76 & 11.21 & 12.691 \\
\hline
\end{tabular}

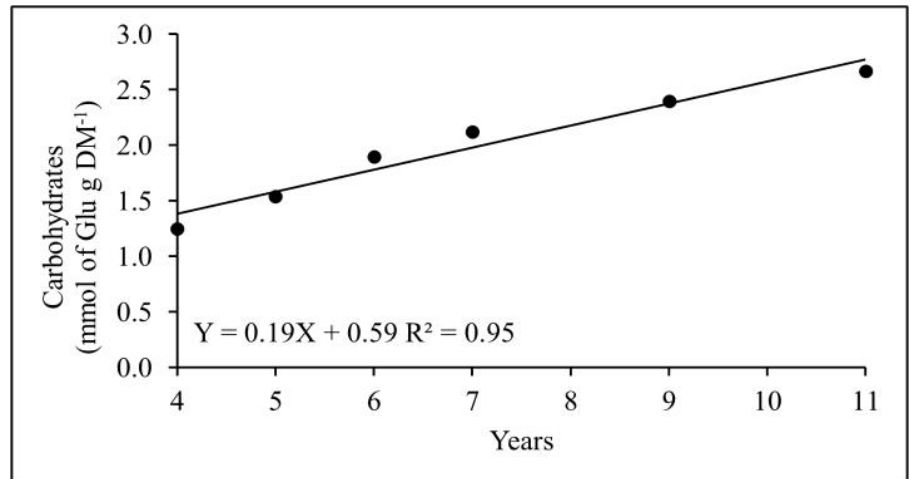

Fig 1. Carbohydrates concentration in different evaluation periods in BRS Manicoré fruits grown in the Brazilian Amazon.

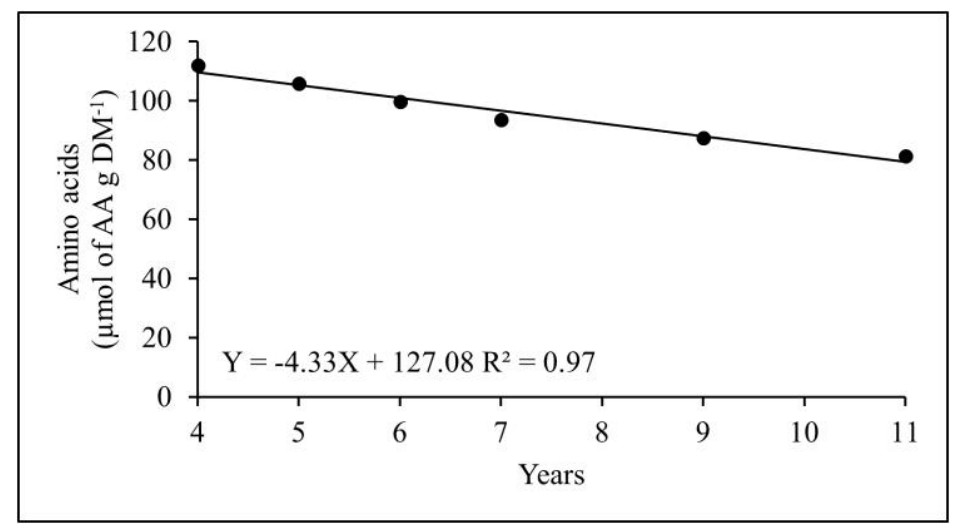

Fig 2. Amino acids concentrations in different evaluation periods in BRS Manicoré fruits grown in the Brazilian Amazon.

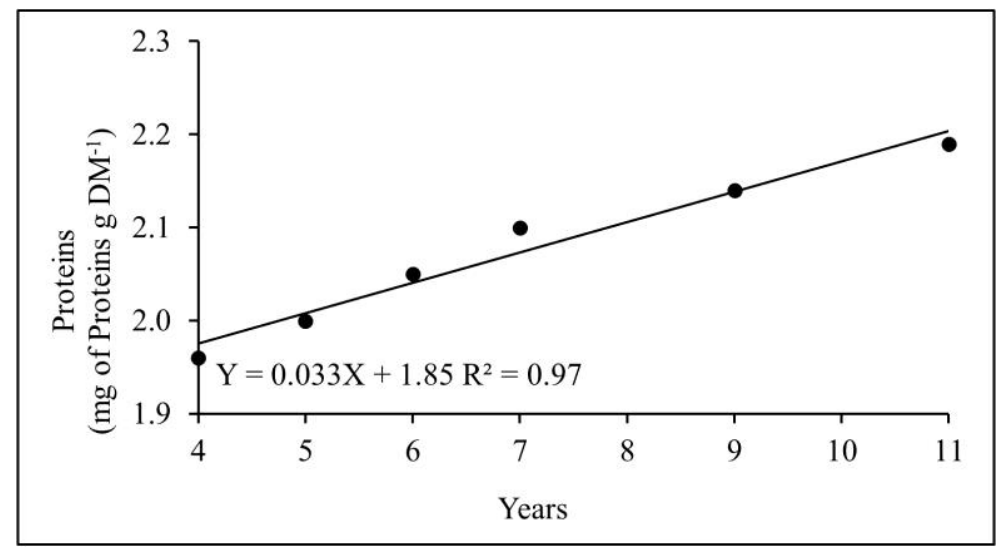

Fig 3. Proteins concentrations in different evaluation periods in BRS Manicoré fruits grown in the Brazilian Amazon. 


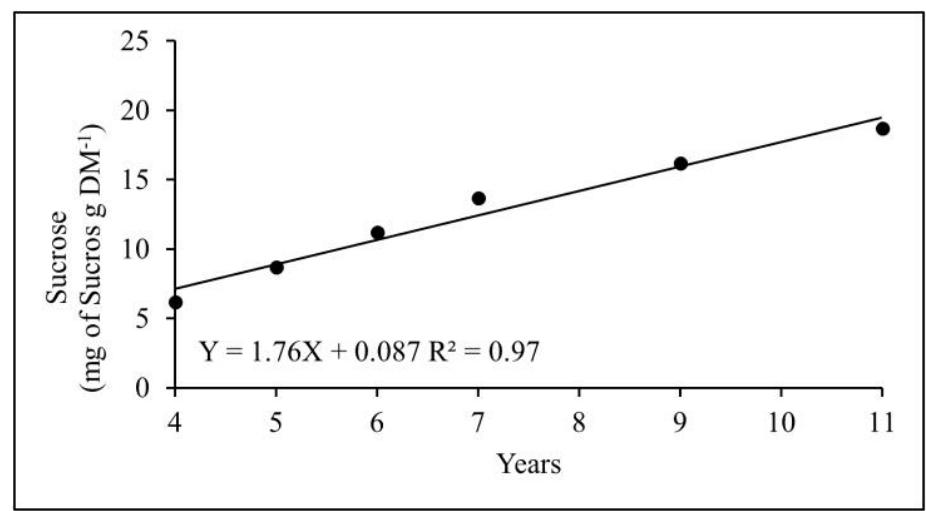

Fig 4. Sucrose concentrations in different evaluation periods in BRS Manicore fruits grown in the Brazilian Amazon.

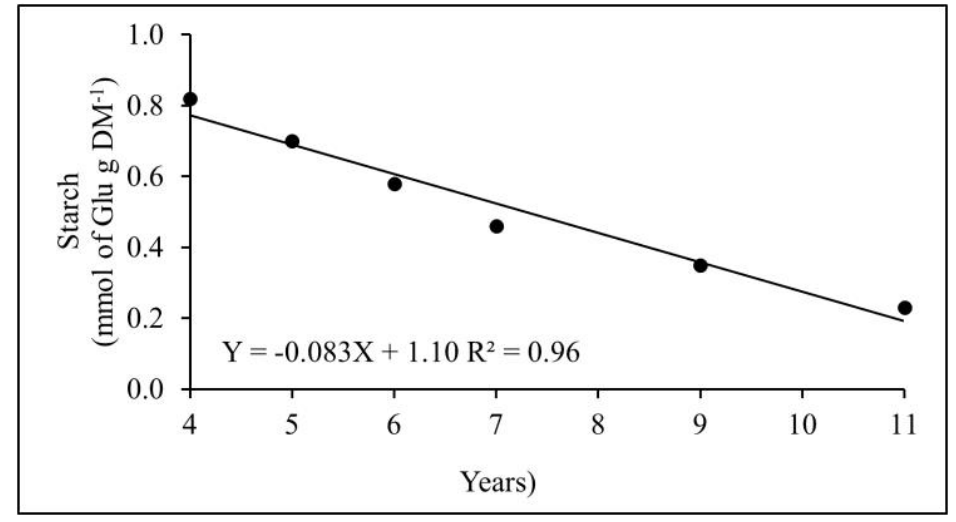

Fig 5. Starch concentrations in different evaluation periods in BRS Manicoré fruits grown in the Brazilian Amazon.

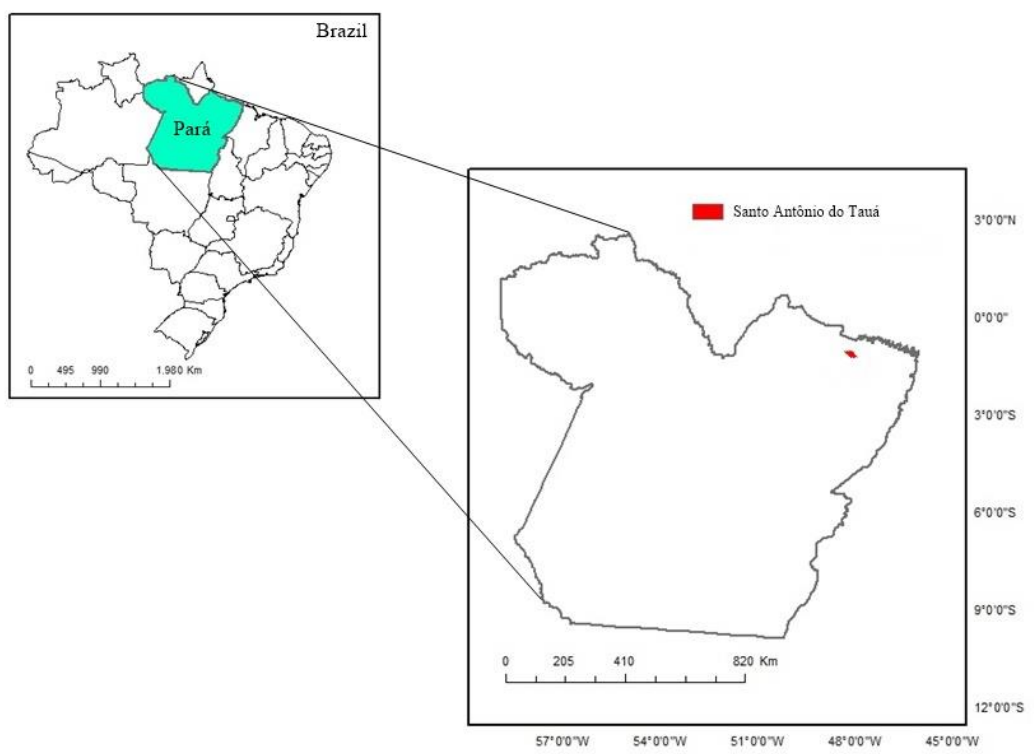

Fig 6. Location map of Santo Antônio do Tauá city, State of Pará, Brazil. 


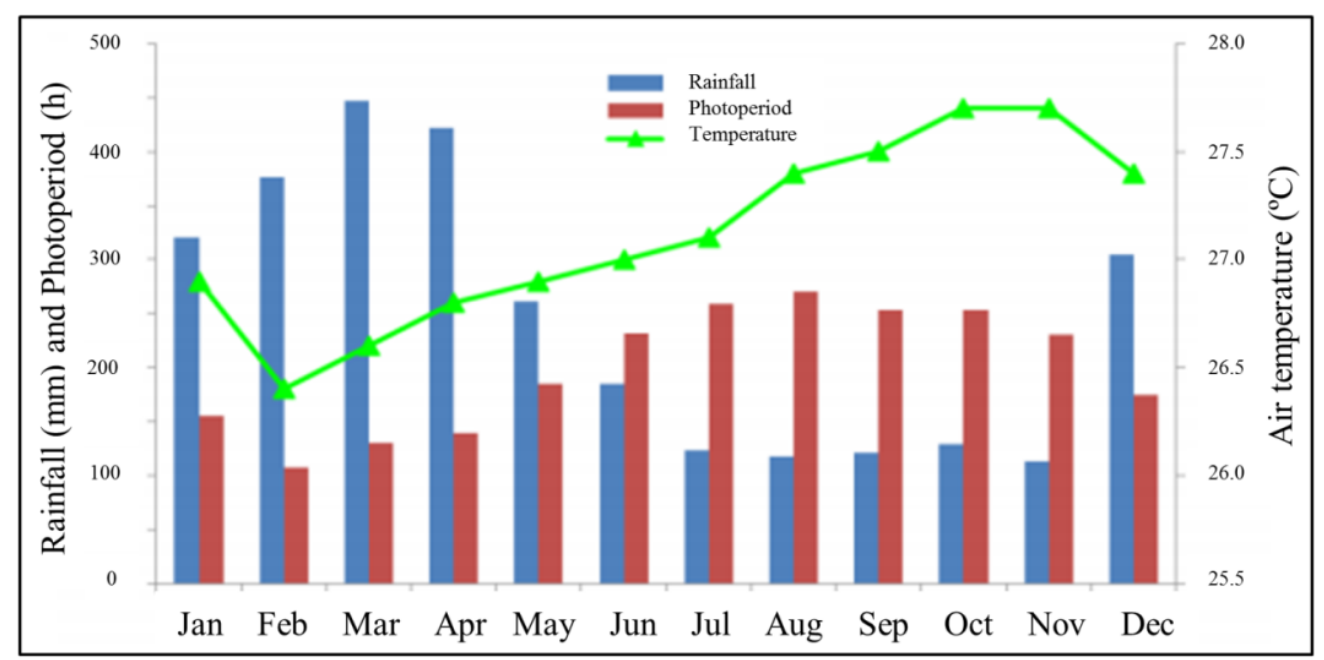

Fig 7. Rainfall, photoperiod and air temperature during the experimental period.

plant during the fruit development (Almeida et al., 2006). The increase in sucrose concentrations is associated with the photosynthetic decrease and starch hydrolysis in sugars by enzyme $\alpha$ and $\beta$-amylase (Kramer and Boyer, 1995). Subsequently, the sucrose are degraded and transported to the various drains in form of sucrose (Taiz and Zeiger, 2013). Freire et al. (2000) evaluated sucrose concentrations in peach palm fruits and observed impressive results at 9 and 11 years of planting (3.60 and $1.30 \%)$.

\section{Starch}

Starch concentrations decreased over the studies years (Fig 5), with adjustment of equation to linear model ( $\mathrm{Y}=-0.083 \mathrm{X}$ $+1.10 R^{2}=0.96$ ), observing higher concentrations of starch at 4 years $\left(0.81 \mathrm{mmol}\right.$ of glutamate $\left.\mathrm{g} \mathrm{DM}^{-1}\right)$ with subsequent, reduction at 11 years of oil palm $(0.23 \mathrm{mmol}$ of glutamate $\mathrm{g}$ $\left.\mathrm{DM}^{-1}\right)$. The reduction of starch concentration with advancement of maturation is common in fruits, since starch is converted to sucrose, desirable reaction in tropical fruits (Rocha et al., 2001; Pinheiro et al., 2007). The highest starch concentration was observed during the maintenance period (first years of plant development), with a subsequent decrease in concentration during the maturation period (last years of plant development). In açaí and peach palm fruits, starch concentrations of 9.3 and $14.1 \%$ were observed, respectively (Freire et al., 2000). Sousa (2013) evaluated the starch concentration in açaí fruits and observed a growth effect until the $6^{\text {th }}$ year, tending to stability from $7^{\text {th }}$ year, with variation of starch concentration from 2 to 7 years of planting of 0.0 to $0.35 \mathrm{mmol}$ of glutamate $\mathrm{g} \mathrm{DM}^{-1}$.

\section{Materials and Methods}

\section{Study localization}

The experiment was carried out at Dendê do Pará Sociedade Anônima (DENPASA) in Santo Antonio do Tauá city, State of Pará, Brazil (Fig 6) (Latitude: $01^{\circ} 08$ '2" / Longitude: $48^{\circ} 00^{\prime} 15^{\prime}$ "). The spatial arrangement of BRS Manicoré hybrid was arranged in $9.0 \mathrm{~m}$ spacing in equilateral triangle, totalizing a stand of 143 plants $\mathrm{ha}^{-1}$. The weather was Af type, according to the Köeppen classification, which is defined as a hot and humid with no dry season defined. The average data of rainfall, photoperiod and air temperature observed during the experimental period are presented in Fig 7.

\section{Plant materials and experimental design}

The experimental design was completely randomized, with six evaluation periods $(4 ; 5 ; 6 ; 7 ; 9$; and 11 years of planting), in four replicates (each sample was composed of four oil palms), totally 24 plants. Oil palm fruits were collected separately and placed on tarpaulins, in which the samples were sent to Phytosanitary Laboratory of DENPASA, proceeding to removal of a sub-sample of known mass. Each sub-sample was placed in a paper bag (sulfite type) and sent to dry in a forced circulation oven at a temperature of 65 to $70^{\circ} \mathrm{C}$, until constant mass. The biochemical analyzes were carried out in Laboratory of Plant Physiology, Universidade Federal Rural da Amazônia (UFRA), Campus of Capitão Poço.

\section{Determination of sucrose}

The determination of sucrose was carried out with $50 \mathrm{mg}$ of leaf powder incubated with $1.5 \mathrm{~mL}$ of $\mathrm{MCW}$ solution (methanol, chloroform, and water) in the proportion of 12:5:3 $(\mathrm{v} / \mathrm{v})$ at $20^{\circ} \mathrm{C}$ for 30 minutes under agitation, centrifuged at $10,000 \mathrm{~g}$ for 10 minutes at $20^{\circ} \mathrm{C}$ then supernatant was removed. Sucrose quantification was carried out at $620 \mathrm{~nm}$, in agreement with Van Handel (1968) using sucrose (Sigma Chemicals) as standard.

\section{Determination of total soluble carbohydrates and starch}

For determination of total soluble carbohydrates $50 \mathrm{mg}$ of leaf powder was incubated with $5 \mathrm{~mL}$ of ultrapure water at $100^{\circ} \mathrm{C}$ for 30 minutes, centrifuged at $2,000 \mathrm{~g}$ for 5 minutes at $20^{\circ} \mathrm{C}$, and supernatant was removed. For determination of starch $50 \mathrm{mg}$ of powder was incubated with $5 \mathrm{~mL}$ of ethanol at $80^{\circ} \mathrm{C}$ for 30 minutes, centrifuged at 2,000 g for 10 minutes at $25^{\circ} \mathrm{C}$, and supernatant was removed. In addition, second extraction was carried out with same powder incubated with $5 \mathrm{~mL}$ of $30 \% \mathrm{HClO}_{4}$ at $25^{\circ} \mathrm{C}$ for 30 minutes and centrifuged in conditions previously described. Supernatants of two extractions were mixed. The quantifications of total soluble carbohydrates and starch were carried out at $490 \mathrm{~nm}$ using method of Dubois et al. (1956), in which glucose (Sigma Chemicals) was used as standard. 


\section{Determination of total soluble amino acids}

$50 \mathrm{mg}$ powder of leave's dry matter was incubated in $5 \mathrm{~mL}$ of sterile distilled water at $100^{\circ} \mathrm{C}$ for 30 minutes and the homogenized mixture was centrifuged at $2,000 \mathrm{~g}$ for 5 minutes at $20^{\circ} \mathrm{C}$, then the supernatant was removed. Quantification of total soluble amino acids was carried out at $570 \mathrm{~nm}$ according to Peoples et al. (1989), using Lasparagine $+\mathrm{L}$-glutamine (Sigma Chemicals) as standard.

\section{Determination of proteins}

Determination of proteins was carried out with $100 \mathrm{mg}$ of powder, incubated in $5 \mathrm{~mL}$ of extraction buffer (Tris- $\mathrm{HCl}$ at $25 \mathrm{mM}$ and $\mathrm{pH}$ 7.6). The homogenized mixture was kept in agitation for 2 hours and centrifuged at 2,000 g for 10 minutes at $20^{\circ} \mathrm{C}$. Quantification of the proteins was carried out at $595 \mathrm{~nm}$ in agreement with Bradford (1976), using albumin bovine (Sigma Chemicals) as standard.

\section{Statistical analysis}

The experimental data were subjected to a variance homogeneity test and error normality test. Data were subjected to analysis of variance by $F$ test $(p<0.05)$ and regression analysis for significant effects using the Sisvar statistic program (Ferreira, 2011).

\section{Conclusion}

A higher total soluble amino acids $(112.11 \mu \mathrm{mol}$ of amino acid $\left.\mathrm{g} \mathrm{DM}^{-1}\right)$ and starch concentrations $(0.81 \mathrm{mmol}$ of glutamate $\mathrm{g} \mathrm{DM}^{-1}$ ) were observed at the initial development stage of oil palm (4 to 5 years of planting). In BRS Manicoré cv., development at 11 years of planting presented higher soluble carbohydrates $\left(2.66 \mathrm{mmol}\right.$ of glutamate $\left.\mathrm{g} \mathrm{DM}^{-1}\right)$, sucrose $\left(18.69 \mathrm{mg}\right.$ of sucrose $\left.\mathrm{g} \mathrm{DM}^{-1}\right)$ and protein concentrations $\left(2.19 \mathrm{mg}\right.$ of protein $\left.\mathrm{g} \mathrm{DM}^{-1}\right)$. The variations of total soluble carbohydrates, total soluble amino acids, total soluble proteins, sucrose, and starch concentrations in oil palm fruits were promoted by BRS Manicoré vegetative differentiation, as well as specific nutritional requirements at each phenological stage in edafoclimatic conditions of Brazilian Amazon. The exploitation of oil palm products could be more beneficial at 11 years of crop development, an age at which greater accumulations of biochemical compounds are occurred in fruits.

\section{Acknowledgments}

The authors are grateful to the Grupo de Estudos de Biodiversidade em Plantas Superiores of Universidade Federal Rural da Amazônia (UFRA) for the collaborations of researchers. For Empresa Brasileira de Pesquisa Agropecuária (EMBRAPA) - Amazônia Oriental for assistance in field work and all support.

\section{References}

Almeida GC, Vilas Boas EVB, Rodrigues LJ, Paula NRF (2006) Ripening delay of 'apple' banana submitted to 1MCP, previously applied to refrigeration. Rev Bras Frutic. 28: 319-321.

Beakbane AB, Slater CHW, Posnette AF (1972) Mycoplasmas in the phloem of coconut, Cocos nucifera L., with lethal yellowing disease. J Hortic Sci. 47: 265-266.
Benicasa MMP (2004) Análise de crescimento de plantas (noções básicas). Jaboticabal, Funep. 42p.

Borges AJ, Collicchio E, Campos GA (2016) A cultura da palma de óleo (Elaeis guineenses Jacq.) no Brasil e no mundo: Aspectos agronômicos e tecnológicos - Uma revisão. Rev Liberato. 17: 1-18.

Bradford MM (1976) A rapid and sensitive method for the quantitation of microgram quantities of protein utilizing the principle of protein-dye binding. Anal Biochem. 72: 248254.

Camargos LS, Aguiar LF, Azevedo RA (2004) Variation in the amino acid concentration during development of Canavalia ensiformes. Biol Plant. 48: 309-312.

Collares D (2011) Produção de cultivares e sementes de dendê na Embrapa. Agroenergia Rev. 2: 30-31.

Cruz ACR, Libardi PL, Carvalho LA, Rocha GC (2005) Water balance in the soil volume of a citrus plant root system. Rev Bras Ci Solo. 29: 1-10.

Dubois M, Gilles KA, Hamilton JK, Rebers PA, Smith F (1956) Colorimetric method for determination of sugars and related substances. Anal Chem. 28: 350- 356.

Freire ES, Souza SMME, Mendonça MAS (2000) Caracterização de frutas nativas da América Latina: Açaí (Euterpe oleracea Mart.). Jaboticabal, Funep. 6p.

Ferreira DF (2011) Sisvar: A computer statistical analysis system. Cienc Agrotec. 35: 1039-1042.

Kok S, Ong-Abdullah M, Ee GC, Namasivayam P (2011) Comparasion of nutrient composition in kernel of tenera and clonal materials of oil palm (Elaeis guineensis Jacq). Food Chem. 129: 1343-1347.

Kramer PJ, Boyer JS (1995) Water relations of plants and soils. San Diego, Academic Press. 495p.

Peoples MB, Faizah AW, Reakasem BE, Herridge DF (1989) Methods for evaluating nitrogen fixation by nodulated legumes in the field. Canberra, Australian Centre for International Agricultural Research. 76p.

Pinheiro ACM, Vilas Boas EVB, Alves AP, Selva M (2007) Ripening of 'apple' banana submitted to 1methylcyclopropene (1-MCP). Rev Bras Frutic. 29: 1-4.

Rist L, Feintrenie L, Levang P (2010) The livelihood impacts of oil palm: Smallholders in Indonésia. Biodivers Conserv. 19: $1009-1024$.

Rocha RHC, Menezes JB, Morais EA, Silva GG, Ambrósio MMQ, Alvez MZ (2001) Use of the starch degradation index for determining maturity in mango 'Tommy Atkins'. Rev Bras Frutic. 23: 302-305.

Sambanthamurthi R, Sundram K, Tan YA (2000) Chemistry and biochemistry of palm oil. Prog Lipid Res. 39: 507-558.

Silva DAS, Viégas IJM, Silva SP, Okumura RS, Oliveira Neto CF, Silva Junior ML, Viégas SFSS, Frazão DAC, Conceição HEO, Araújo FRR (2016) Multivariate analysis on dry mass variables in cupuassu progênies (Theobroma grandiflorum) in function of the plant age. Afr J Agric Res. 11: $1227-1236$

Sousa GO (2013) Estoque de carbono, composição bioquímica em diferentes partes da planta e análise econômica da plantios de açaizeiros (Euterpe oleracea Mart.) em sistemas agroflorestais no Município de ToméAçu, PA. 96p. Thesis (Doctorate in Agrarian Sciences) Universidade Federal Rural da Amazônia: Embrapa Amazônia Oriental, Belém city, State of Pará, Brazil.

Sterling F, Alvorado A (1993) Determinación del estado de madurez del racimo de palma aceitera associado com la maxima tasa de extracción de aceite. Agron Costarric. 2: 71-76.

Taiz L, Zeiger E (2013) Fisiologia vegetal. $5^{\text {rd }}$ edn. Porto Alegre, Artmed. 954p. 
Tan CH, Ghazali HM, Kuntom A, Tan CP, Ariffin AA (2009) Extraction and physicochemical properties of low free fatty acid crude palm oil. Food Chem. 113: 645-650.

Tranbarger TJ, Dussert S, Joët T, Argout X, Summo M, Champion A, Cros D, Omore A, Nouy B, Morcillo F (2011) Regulatory mechanisms underlying oil palm fruit mesocarp maturation, ripening, and functional specialization in lipid and carotenoid metabolism. Plant Physiol. 156: 564-584.

Van Handel E (1968) Direct microdetermination of sucrose. Anal Biochem. 22: 280-283.

Villela AA, Jaccoud DB, Rosa LP, Freitas MV (2014) Status and prospects of oil palm in the Brazilian Amazon. Biomass Bioenergy. 67: 270-278. 